\section{The organizational restructuring performative act under shareholder value management ideology}

\author{
Patrícia Saltorato \\ Glauco Benatti \\ Federal University of São Carlos, Department of \\ Production Engineering, Sorocaba, Brazil
}

Received on

$12 / 02 / 2015$

Approved on

$11 / 18 / 2016$

Responsible editor:

Prof. Dr. J. Ignacio Canales

Evaluation process:

Double Blind Review

\begin{abstract}
Purpose - This paper's objective is to present the dynamics involving an organizational restructuring process conducted in a Brazilian subsidiary of a centenary American industrial corporation which claimed to be seeking, by means of this process, to increase the value of the company's shares, but, which results reveal the distance between the promises and outcomes of this process, unveiling the symbolic-performative nature of such a process.
\end{abstract}

Methodology - The chosen research method was the case study. The data collection involved the participant observation of a company manager (2010-2015); the conduction of non-structured interviews to the company's managers, directors and CFO (2013-2015); documental research to the company's internal and public sources (2010-2015); and bibliographical research to scientific papers, business press, market analysts and specialized media (2010-2015).

Results - The narratives of success found in the company's reports portray the restructuring myth as a continuous strategy, through which the company reinforces its efforts in delivering good results to shareholders. And, despite the outcomes of the case study not supporting these narratives, its performative nature legitimize the company's commitment to the SHV management ideology towards stakeholders of the capital market, even in face of the adoption of antishareholders' postures, such as anti-takeovers measures, the merging of the CEO and Chairman positions, its CEO perks, etc.

Contributions - Paradoxically, although the researched company operates under the cold logic of finances, and under pressure to create shareholder value, it revealed to be subject to the dynamics in which the search for symbolic legitimacy plays a decisive role in maintaining its position within the hierarchy of the socially constructed field of the Management in face of other stakeholders present in the field, reinvigorating the precepts of Bourdieu's Field Theory and the NeoInstitutional Theory.

Keywords - Performative organizational restructuring; financialization; Celebrity CEO; symbolism, myth.

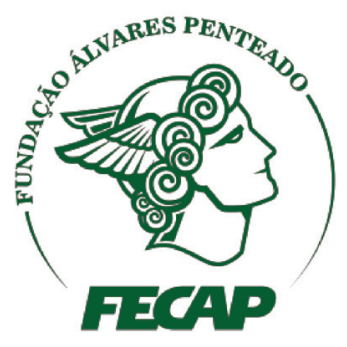

\section{Review of Business} Management

DOI: $10.7819 /$ rbgn.v 19i64.2875 


\section{Introduction}

From the late 1970s on, the Shareholder Value (SHV) management ideology began to increasingly understand, control and manage companies as portfolios composed of organizational units measured by financial metrics (Dobbin $\&$ Jung, 2010). The emergence of this management ideology can be portrayed as a social construction of a bourdieusian organizational field. In this process, capital market stakeholders holding hierarchically privileged positions within the field structure, had legitimized its new functioning rules, or its habitus (Bourdieu, 1989), defining values, beliefs, myths and rituals to be perceived as symbols of value creation and to be reproduced by corporate management speeches by stakeholders sharing this ideology.

One of the most symbolic and powerful values that represents this ideology refers to the belief in the organizational restructuring processes as an instrument to create shareholder value (Froud et al., 2006). This has led organizational restructuring success narratives to be exhaustively reproduced within the field, despite the distance between their promises (creating shareholder value) and outcomes (only reducing labor costs). Taking that into account, this paper explores the case of a restructuring process undertaken in the Brazilian subsidiary of one of Fortune 500's largest and longstanding American industrial corporations, that under the capital market's pressure for increasing SHV, focused during the researched period, on several strategies to respond to this pressure, highlighting the power of this myth. Both the company's discourse and the performativity of its restructuring process symbolize to the capital market's stakeholders its belief in the value creation by means of the organizational process.

The analyzed company's annual reports portray the restructuring organizational process as a continuous strategy, by means of which the company reinforces its commitment to deliver better numbers (and, also reverse bad ones). This institutional literature revealed itself an emblematic tool through which the company honors SHV ideology, telling stories about what it intends to do (or is doing) regarding the reproduction of values made legitimate by SHV ideology, as an attempt to meet capital market stakeholders' expectations. So, although the subsidiary's disappointing restructuring results do not support the success reports, this process certainly performs its legitimizing role.

Corroborating the hypothesis of a highly symbolic context, Froud et al. (2006) stated that truly the management of large companies under the SHV ideology began to incorporate a great deal of performativity:

\begin{abstract}
"When management is about doing as well as saying it is necessary to extend the concept of performance to include management initiatives that 'show' the strategy is being enacted. Under the stock market pressure, these are now a characteristic part of large company management which includes enactment as well as telling stories" (Froud et al., 2006, p. 129).
\end{abstract}

The relevance of this research lies on the proposition of an alternative conceptual relationship between the reorientation of American management discourse (Froud et al., 2006), the Agency Theory (Jensen \& Meckling, 1976) and the SHV ideology (Fligstein, 1990). The SHV ideology, as presented here, intends to go beyond the traditionally used formulations of the Agency Theory as it employs the bourdieusian field notion (Bourdieu, 1989) to better explain beliefs, values, rituals and myths made legitimate by stakeholders of SHV organizational field, thus integrating the reorientation of American management discourse from the late $20^{\text {th }}$ century to the emergence of the $21^{\text {st }}$ century CEO Celebrity phenomenon (Wade et al., 2006; Hayward et al., 2004; Sinha et al., 2012). 


\section{Methodology}

The current research involves a qualitative approach to explore the symbolic/performative nature of the restructuring process that took place in the Brazilian subsidiary of an American industrial corporation; it reveals the power of such a myth, as it focuses on the distance between the promises and the outcomes of the process. To do so, both a theoretical and an empirical approach were carried out, combining a set of methodological tools and data collection instruments, described below:

\section{I Theoretical approach}

This approach intends to revisit and reconstruct the theories related to the themes studied here as well as to analyze the company's official documents that could help better explain and explore the empirical findings of this research. This approach was undertaken by both bibliographical and documental research.

\section{I.I Bibliographical research}

Bibliographical research enabled portraying the ideology of Shareholder Value management (SHV) as a social construction marked by the mid-1970's reorientation of management discourse according to a bourdieusian notion of organizational field. Such a field symbolizes a structured/hierarchic social subsystem according to the manipulation of different sources of capital by diverse stakeholders from the capital market and its resulting acts.

In that sense, bibliographical research involved the articulation of concepts concerning the social construction of reality (Berg \& Luckman, 1966); the social construction of markets (Fligstein, 1990); Agency Theory formulations (Jensen \& Meckling, 1976; Dobbin \& Jung, 2010); the bourdieusian Field Theory (Bourdieu, 1989); Mimetic Isomorphism (DiMaggio \& Powell, 1991); and Economic Sociology (Grun, 1999; Fligstein, 1990; Bourdieu, 1989), to explore topics related to the institutionalization of SHV ideology and its corollary: financial management (Useem, 1993).

Additionally, directly related to those, we will examine the legitimacy of beliefs and values disseminated by this ideology, as well as to the honor of organizational restructuring (Froud et al., 2006) and the emergence of the CEO Celebrity (Wade et al., 2006; Hayward et al., 2004; Sinha et al., 2012) as a means to create SHV.

Thus, based on these theoretical assumptions, this study proposes to explore the organizational restructuring case of a large American corporation's Brazilian subsidiary as a socially constructed performative act in the SHV ideology organizational field, as opposed to the direct (and passive) approach derived solely from Agency Theory formulations.

\section{I.2 Documental research}

This source of information provided upto-date data about the analyzed firm influential stakeholders' movements, from 2010 to 2015, through the examination of the company's public information, reports and websites, as well as internal documents concerning the restructuring process of the Brazilian subsidiary. The business press and market analysts' opinions aired in specialized media about the company's performance from 2010 to 2015 were also considered.

The company's institutional literature here analyzed, from 2010 to 2015, was an emblematic instrument through which the company honors SHV ideology, narrating its intentions regarding the reproduction of values legitimized under that management ideology attempting to meet the expectations of the stakeholders from the capital market. The company's annual reports portray the restructuring process as a continuous strategy, through which the company's commitment to deliver better numbers (and, also reverse bad ones) is reinforced.

Although the examination of the Brazilian subsidiary's disappointing results did not support the company's success narratives, in its strict sense, 
the performative role that this process played, legitimized the company's devotion towards the SHV ideology discourse, and hence was understood as legitimate.

\subsection{Empirical approach}

Considering the bibliographical research results (Froud et al., 2006; Goldstein, 2012; Hirsch \& De Soucey, 2006), it was realized that organizational restructuring processes have been used by large corporations as one of the most symbolic and powerful beliefs that represent their communion with the ideology of SHV. Moreover, and besides the documental research results (Annual Reports 2010-2015), their narratives revere such a belief, portraying the analyzed company as one that have systematically reproduced values associated to the mentioned ideology. The empirical approach of this research involved the case study of a restructuring process undertaken in the Brazilian subsidiary of one of the largest and longstanding industrial American corporations listed in Fortune 500, highlighting the gap between its promises and outcomes, also revealing the power of such a myth. The case study was empirically supported by interviews and a participant observation of a manager of the analyzed company from 2009 to 2015 .

\subsection{Case study: interviews and participant observation}

This case study involved carrying out 30 semi-structured interviews from 2010 to 2015 with six managers, two directors and the company's Latin American CFO regarding the restructuring process of the researched company, hereby called Corp. These interviews were done before, during and after the restructuring process, and inside as well as outside the company. The interviewed managers were chosen based on the participant-observer-researcher's prior knowledge that they would occupy strategic positions after the restructuring. Each of these managers were interviewed four times (on average for about 30 to 40 minutes each) between 2010 and 2015. The
Brazilian subsidiary only employs two directors, who were part of the interviewers' sampling; the CFO participated because he moved to Florida, a consequence of the restructuring. Directors and the CFO were interviewed twice, for approximately 30 minutes each, by the participant-observer-manager (researcher).

The participant-observation of the researcher-manager occurred from 2009 to 2015, and besides conducting these interviews, he actively participated of the restructuring process, implementing it, and therefore having access to official documents and decision making that better enabled him to explore this case study. The participant-observation of this researchermanager greatly contributed to avoid a research exclusively centered on the discourses of those interviewed. As pointed out by Henry (1992), these discourses can present certain dilemmas as self-praise discourses, the attempt to overestimate specific characteristics of the observed process, or, the use of catchphrases/jargons that might render but a minor contribution to the analysis.

In that sense, the interviews were then triangulated with other sources of information; with that of other employees (collected nonsystematically by the manager's participantobservation, as well as his daily interaction with them during years of observation inside the company); with internal official documents, institutional communication and bibliographical findings, which aimed to compare their argumentative rhetoric with these other sources. The confrontation and comparison among these different perspectives can shed light over these stakeholders' dynamics and their perceptions of the restructuring as a process that creates value in the SHV context in which the analyzed company operates.

\section{From social construction of the SHV organizational field to emergence of the CEO Celebrity}

The process of institutionalization of managers in the 1950 s already displayed the 
academic capital experienced by the incipient Business Schools, responsible for the formation, professionalization and updating of that new professional class. The Business Schools became legitimately responsible for the systematization of the theoretical content related to the management science and, thus, began conferring professional legitimacy to managers. These stakeholders have played a rather relevant role in the reorientation of the current American Management discourse, up to then centered on the merely productive intervention, mainly performed by professionals with strictly technical formation towards a new one based on the novelties of marketing, human resources and strategy (Froud et al., 2006), the latter, the queen of these novelties.

Managers saw their decisions become increasingly supported by the emergence/ dissemination of a new set of conceptual/analytical tools, values, beliefs, and rituals based on new lexicons fomented by the Business Schools (and reproduced by the new professional class), both groups of stakeholders seeking the new rules of the management field. Alongside these stakeholders were the Business Press stakeholders, also engaged in the consolidation of the field, reproducing the newly born modern companies' ways of thinking, acting and talking, under the control of these managers (also modernizing). Hence, successful managerial performances in American corporations institutionalized these behaviors as legitimate symbols within the management's organizational field (and of the capitalist success itself). This hierarchy and social order within the field and legitimacy outside the field would remain relatively stable for still two decades.

However, from the mid-1970s' on, American corporations faced increasingly profitability losses (Fligstein, 1990) leading them to question if their management models might be somehow wrong and how this could be changed. According to Dobbin and Jung (2010), the answers to these inquiries came from several places, including the lean Japanese production, the Italian model of small companies and the French industrial coordination, among others. One of them, the Agency Theory (Jensen \& Meckling, 1976) offered both the diagnosis and the cure for the problem of low profitability, both embedded in academic legitimacy and their postulants, pointing to asymmetrical information and the lack of alignment between managers and owners as potential management problems. According to the agency's theoreticians, the managers had sought the companies' expansion, investing its profitability in unnecessary expansions, seeking stability (as opposed to risk assumption), the maintenance of their status and personal prestige, among other privileges to the detriment of seeking increased shareholder return (Dobbin \& Jung, 2010).

The new approach for administrating large open capital companies was supported by the growing deregulation of financial markets and its formulations encouraged the intensification of capital market management, to the detriment of a relative current managerial autonomy. Thus, this new approach, as well as its predecessor (that focused on the Production centered Management discourse to another permeable to Marketing, Human Resources and Strategy), would again focus its discourse, thus supporting the insertion and strengthening of new stakeholders within the field. These stakeholders, associated to several sources of symbolic capital (organizational, legal, economic, financial, social, academic, etc...) employed the latter to restructure their hierarchic positions amid the Management's reconstruction of the bourdieusian organizational field (Bourdieu, 1989), trying to legitimize a new management ideology that would better stand for the interests of the new (and more influential) stakeholders in the field. Among these, institutional investors (Useem, 1993) held privileged positions in the new field structure which conferred them the ability to exercise several kinds of power over the other stakeholders, such as, for instance, strongly influence the field's functioning rules, thus legitimizing a new set of values and beliefs, or, its habitus (Bourdieu, 1989; Leão et al., 2013). The new habitus of financial management field 
may be unfolded/understood by means of the following features:

- Replacement of the logic of profit maximization by the logic of maximization of return to the shareholder;

- Replacement of productive logic by financial logic;

- Transformation of internal firm relationships into market ones;

- Pursuit of the inorganic growth strategy;

- Belief in organizational restructuring as a myth that creates value for the shareholder;

- The privilege of liquidity and shorttermism culture;

- The extinction of anti-takeovers measures (in a takeover situation surcharges paid can benefit shareholders, even if in the short-term);

- The rise of activist investors;

- The need of an external and independent administration board, and the division of the CEO and Chairman positions between different executives;

- The alignment of executives' wages and the increase of the value of the company's shares; and

- The employment of financial metrics to measure, compare, assess, invest and disinvest in non-financial organizational units that (although profitable) may be viewed as "destroyers" of shareholder value. Although the habitus associated to the SHV ideology may be unfolded/understood into other features not mentioned above, the reproduction of some of the above ones by large companies under the capital market pressure does symbolize their reverence towards this ideology. The emergence of this habitus (and as well its continuous reconstruction) is the direct result of the manipulation of varied sources of symbolic capital by the stakeholders in better hierarchical positions (thus, more powerful) present in the social construction of the SHV ideology from the mid-1970s on, such as:
- Institutional and activist investors;

- Legislators, lobbyists and other advocates of financial deregulation;

- Market analysts, risk agencies and business press;

- Financial-economist theoreticians and Business Schools;

- Consulting companies and business advisory industry in general; and

- Executives and fund managers.

When these capital market stakeholders (among others) began legitimizing the above functioning rules, in association with the management's organizational field in large American corporations, the habitus of this field became institutionalized by SHV ideology. Moreover, the narratives of success experienced by the companies active in this context gradually became successful references to other companies, which were isomorphically mimetized (DiMaggio \& Powell, 1991) reorienting other companies' discourses towards another one, in which the efforts regarding maximizing the shareholder return should be publicly explored.

Hence, managers, since the $1950 \mathrm{~s}$, legitimized as symbols of successful companies (Chandler, 1962) at the same time they found themselves threatened, to a certain extent, by the SHV ideology's anti-managerial impulse, noticed that to overcome it, they would have to somehow, profess/align their discourses to the new management ideology, reproducing its most emblematic values in their strategies and, thus, symbolically manage the capital market pressure in their favor (Roe , 1994; MacDuffie, 1996; Capelli, 2000; Hallock, 2003; Zajac \& Westphal, 2004; Goldstein, 2012; Westphal \& Zajac 1998, 2001).

Parallel to these stakeholders' accurate perception, amid the field consolidation, the numerous financial scandals, speculation bubbles and financial crisis began to threaten both the hierarchical positions so far established by the new stakeholders, the field institutions, as well as their legitimized values and rules, rearranging its social order, and revealing during the process, the 
emergence of a new actor, the "Celebrity CEOs" (Wade et al., 2006; Hayward et al., 2004), and the symbolic power of their (well-staged and paid) performances within the construction of the field. These stakeholders had engaged in billionaire acquisition deals, launched massive (and sometimes performative) restructuring processes, assumed large risks, announced, but not, necessarily implemented, executive longterm compensation packages, etc., symbolizing their compliance towards the SHV ideology. The capital market rewarded these announcements through the share price increase, even though some were not even implemented (Zajac \& Westphal, 2004).

According to Goldstein (2012), this shows that the anti-managerial impulse of the SHV ideology is quite symbolic, especially considering that one of its major contradictions was that it neither resulted in the cost reduction of management level nor in a significant shift of the employees to owners'/shareholders' corporative revenue. Still according to the author, the SHV era has coincided with a massive revenue redistribution from (non-management) workers to executives.

Thus, amidst the consolidation of the field and institutionalization of the Agency Theory prescriptions (Jensen \& Meckling, 1976; Dobbin \& Jung, 2010), large open capital companies managed under the SHV ideology became increasingly controlled as portfolios composed of organizational units measured by financial metrics, highly vulnerable to the scrutiny of the capital market, and guided by executives who, amid the field consolidation, reinvented themselves (as well as the Management-oriented organizational field) and, in the process, became billionaires (Froud et al., 2006), attaining the CEO Celebrity status (Wade et al., 2006, Hayward et al., 2004, Sinha et al., 2012). As a direct consequence of this, these companies began to include in their discourse, both the storytelling strategies (Boje, Oswick \& Ford, 2004; Fleming $\&$ Spicer, 2014) and the enactments (Froud et al.,
2006) associated to them in order to show that the new rules of the field's operation (its habitus) were being set in motion according to what the discourse preached, although this alignment did not always take place in reality as shown in the following case study (Benatti, 2016).

\section{The art of storytelling by Corp: myths, ceremonies and reports of SHV ideology}

The present case study focuses on the restructuring process of the Brazilian operation of one of the largest American automation and control equipment manufacturers here called Corp. This corporation is among the top 100 companies listed in Fortune 500, founded in 1890 and currently has 150.000 employees distributed among its 240 factories, of which 160 are outside the USA. The American Headquarters' operations were until 2015 organized around five Business Units (BU) responsible for specific product lines (among these, three BUs operated in Brazil until 2014).

The main official document through which Corp shares its reverence towards the Shareholder Value discourse is its annual report, an emblematic source of the values, beliefs, myths and rituals legitimized by this ideology. Through these documents, the company shares stories about what is being done (and what it intends to do), concerning the reproduction of these values that have in mind the expectations of both the investors and the capital market stakeholders. It is directed towards an internal audience, aiming the catechization of their collaborators.

The company's official literature, shown with a distinctive aesthetic presentation,

is dedicated to boost the capital market's trust in the company's capacity to deliver better numbers (and sometimes to reverse bad ones), promising to set in motion strategies rhetorically anchored in the new structuring habitus (Bourdieu, 1989) of the SHV field. Thus, this habitus began to contemplate the rules, sometimes more explicitly, sometimes subtler by the stakeholders in better positions in the 
hierarchy of the field that, in Corp, have unfolded into actions, sometimes more tangible, at others more symbolic and performative, made public through its annual reports, press statements, CEO appearances, analysts' opinions, board composition, growth strategies, etc., as well as denying some of these.

Corp has a 125-year tradition in the capital goods manufacturing industry. However, the story that the company mostly sells in its annual reports refers to its 59 years of successive increasing dividends, addressed to its institutional investors, who hold $76.45 \%$ of the company shares. Among Corp's major shareholders are the Vanguard Group, the State Street Corporation, the BlackRock Institutional Trust Company, the Barrow, Hanley \& Mewhinney Strauss Inc. and the JP Morgan Chase.

The Business Units (BUs) results (in terms of sales, earnings, margins, total assets, investments in restructurings and acquisitions) are made individually available by the company's annual reports. However, the value creation by these BUs are not publicly shared by the company's annual reports, despite the SHV's ideology preach the need for transparency.

The BUs individual results are used as parameters for Corp's investment/disinvestment decisions. Thus, the company seeks to transform internal firm relationships between BUs into market ones (of which Corp-Brazil restructuring symbolizes an emblematic example of such an effort). According to the company, by means of disinvestments, the company aims to increase shareholders' returns, attempting de-diversification and concentration on the company's core business, as such dissolving several businesses annually, which it believes present a slow growth (Annual Reports, 2010-2015).

According to Corp's CFO, internally, the company employs value creation metrics such as the Economic Profit to instruct (non-financial) managers the financial implications of their (nonfinancial) decisions. The company also employs metrics as ROCE (Return on Capital Employed) and EVA (Economic Value Added) before taking any investment decision. Still, according to him, there is an internal procedure, the Appropriation Request, a template, which, when complete, demonstrates each investment return (that is, its capital cost vs. opportunity cost) and compares its expected profitability with the profits obtained by the Headquarters in the capital market. The CFO also told that the board set risk categories that each BU could take on, and based on these categories, only some BUs became recipients of certain investments.

However, in public, in its yearly reports, the company made available the following information: dividend value per share, operational cash flow, total capital return (RT) and return on equity (ROE). The publication of Corp's results by means of these listings in its financial reports is always done through conferences calls with market analysts (as the ones who operate through Seeking Alpha, The Value Investor, Part-Time Investor, Passive Income Pursuit, Financially Free Investor, Willow Street Investments, Balanced Investing, Winning Strategies, Dividends4life, SA News Investor, Sure Dividends, etc.) with whom the company shares the best information aiming at the release by them of favorable opinions regarding the company's performance. Up to 2014, these capital market stakeholders contributed a great deal to the emission of favorable opinions related to the company performance, although, from 2015 on, they began to question severely and publicly the company's decisions, pressing it to make new acquisitions (one of the most noticeable aspects of the materialization of the company's SHV ideology, explored next).

Myths and ceremonies (Meyer \& Rowan, 1977) related to SHV ideology are largely disseminated through training courses, corporate seminars, conferences with analysts and shareholders, company's internal news, radio and close caption TV systems, board meetings specialized media statements, annual reports, CEO and Investor Relationships Officer interviews to the CNBC to elevator chats, as the 
stock options' remunerations is not restricted to the executives. The materialization of the formal structure of the SHV ideology reflects the resignificance of the company's concept related to the value of its shares in the capital market. The company's appetite for acquisitions and its board meetings ceremonials hosted by its Celebrity CEO also embody these concerns and are explored next.

\section{I Corp's board administration ceremonial and its Celebrity CEO}

Corp's Board Administration is comprised of 20 members, of which five are direct representatives of banks, investment funds, consultancies, private equity funds, and other financial institutions; all, relevant financial stakeholders within the social construction of the SHV field (Bloomberg, 2015). Considering SHV ideology's pressure for a more independent board (Dobbin \& Jung, 2010), at Corp, the proportion between inside members and outside ones is 11 to 9. Among the 11 insiders, only five participate of a single board (Corp itself). And, while an insider has an average of 20 to 40 connections with other company board members, the outside members have an average of 200 connections with other company board members (Bloomberg, 2015). These participations in other board administrations (board interlocking) greatly contribute to reproduce the SHV's ideology discourse, as the board meetings involve a great deal of storytelling (Boje, Oswick \& Ford, 2004; Fleming \& Spicer, 2014) and exchange of experiences, through which the values, beliefs and myths legitimized by the habitus of the field under construction are shared, disseminated or banned.

All the company board members are individual investors of it (Bloomberg, 2015). This fact symbolizes that not only is Corp following the Agency Theory (Jensen \& Meckling, 1976) of aligning its executives' interests to that of the shareholders, through changes in remuneration schemes, as it has also extended this alignment to all board members. Additionally, the company Chairman is also its biggest individual stock holder. However, the Chairman of the Board is also the company's CEO, contradicting, thus, the opposite standing of the Agency Theory (Dobbin \& Jung, 2010).

Another controversy between the recommendations of Agency Theory and Corp. are in the privileges that its $\mathrm{CEO} /$ chairman enjoys. Every year, he receives close to US\$ 500.000 in perquisites for personal use of company cars and airplanes, payments of club fees, tickets for sports, cultural and entertainment events, health care, security services and personal consulting for financial planning and tax payments, which also contradicts the SHV discourse of monitoring managerial actions. In addition, despite the company statement of abolishing anti-takeover measures (perceived as an illegitimate measure within the SHV ideology discourse) the CEO/ Chairman has assured the right of a Golden Parachute of US\$ 50 million in stock options in a takeover case. Moreover, since 1989, Corp's board established another anti-takeover measure, abolishing the cumulative vote for board members. Hence, a shareholder favorable to a takeover is forbidden to concentrate his/her votes on a single candidate who is also favorable to the takeover (and opposed to directors' interests) since, in this way, with the cumulative vote for directors, shareholders could vote as many times as their number of shares allowed.

Despite the contradictions between the SHV Ideology and the Agency Theory formulations (Jensen \& Meckling, 1976) and the empirical results collected, the CEO/Chairman has been aggressively transferring the company's productive operations to less regulated labor markets, especially China, thus eliminating nearly 20.000 working positions in the USA since 2009. Despite this (or due precisely to this) the 14-year Corp CEO (and 11 years as CEO/Chairman) was appointed for two years in a row, as a Celebrity CEO (Wade et al., 2006; Hayward et al., 2004; Sinha et al., 2012) by the Institutional Investors Magazine, which, based on 900 market analysts' opinions, elected him, "the best American CEO 
in the electric company industry", demonstrating, as Goldstein (2012) pointed out, the symbolism of SHV's anti-management inclination.

Thus, Corp's Celebrity CEO symbolic power can be perceived by the perquisites he/ she enjoys, the Golden Parachutes, the antitakeover measures approved by the board under their command, as well as by the fact that he/she holds both the CEO and Chairman positions. Although he/she embodies these symbols of power (contradicting the habitus of the SHV field) the company's annual reports go on assuring Corp's commitment to the SHV ideology, mainly through the maintenance of seats for the capital market stakeholders in its board. Thus, nonetheless, the presence of market stakeholders in the board may only symbolize that the market is present, (not necessarily imposing anything). It may also symbolize that the company listens to the market, and not necessarily meets its needs (in case they are being addressed). Because the decisions apparently taken during the board ceremonials may be partially (or totally) taken elsewhere, especially considering the board members interlocking connections and that the meetings themselves are socially constructed ceremonials embedded in their own systems of interpretation and opinion (Hayward et al., 2004) developed and shared by their members. Based on this, the stage for the enactment of more symbolic and performative actions is set up, according to its restructuring movements.

\subsection{Financial Corp: the acquisition/ spinoff alchemy vs. the illusionism of restructuring}

According to Froud et al. (2006) the economic growth of large companies based on the product market faces structural limitations due to its functioning and structure, frustrating the capital market expectations related to investment return. These expectations can only be fulfilled through reports of increases in earnings related to the increase in sales revenues. If sales revenue growth cannot be achieved through organic growth, then the company has no choice but to grow inorganically, provided by the strategy of buying and selling other companies, recommended by the SHV ideology.

The examination of Corp's financial results revealed the role that its serial acquisitions played in the company's struggle to create value for the shareholder. The company's CFO revealed that, in the USA, Corp employs professionals exclusively, continuously and systematically to bunt acquisitions which might boost this value creation, through the incorporation of acquired companies' Earnings Before Interest, Taxes, Depreciation and Amortization/EBITDA, impacting instantly and positively the company's cash flow.

Although the direct positive impact on the share value may be inconclusive (Eccles, Lanes, Wilson, 1999; Marshal, 2001; Cartwright \& Schoenberger, 2006; Jespersen, 2002; Fridolfsson \& Stennek, 2005; Accenture, 2012; Deloitte, 2012; PWC, 2013); the increase on cash flow, on market share and on EBITDA, that were automatically incorporated into Corp's numbers, and influence positively (and symbolically) the capital market stakeholders, perpetuating the myth, according to which this strategy should be undertaken as a means to create value to shareholders. As stated by Dobbin and Jung (2010), if the market believes that the M\&A transactions create value, then they create it.

Alongside the acquisitions, there are the restructurings, as a belief derived from the SHV ideology. According to the company's annual reports, its restructuring moves involve dislocation to lower cost sites, closing of product lines with bad results, the costs of shutting down facilities and others related to productive operations (the Brazilian subsidiary case).

A contrasting difference can be observed when comparing the company's total investment in acquisitions and restructuring from 2010 to 2014. During this period, while Corp dedicated US\$ 459 million $(2.84 \%$ of its operational profit) to the restructuring strategy, US\$ 4.37 
billion (27.08\% of its operational profit) were invested in the acquisition strategy. Considering the contrasting difference of when the company invested financially in each strategy, it must be considered that the compulsive acquisition strategy combined with financial engineering may be contributing much more to the company's delivering its 59 consecutive years of increasing dividends than the results of the restructuring processes, although the argument of value creation to the shareholder used by the company has been the keynote for the restructuring presented here.
Figure 1, below, portrays Corp's net sales and gross profit curves evolution and is directly associated to the acquisitions strategy, showing that this strategy maintained the sales increase and profitability until the 2008 crisis as it also did again after a 2.5 billion-dollar acquisition in 2010. Nevertheless, when it comes to the Sales Goods and Administrative Costs (SGA) issue, the numbers do not confirm whether synergic gains were reached through the acquired companies, as they evolve accordingly to the company sales.

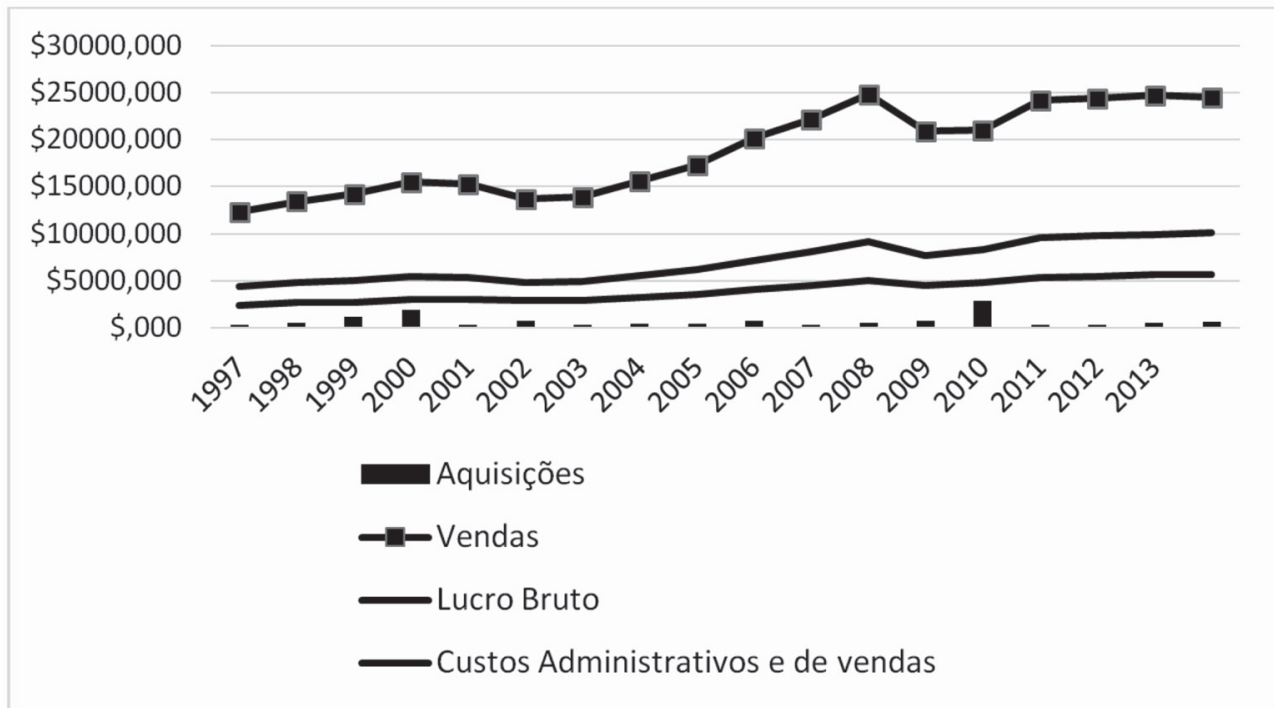

Figure 1 - Corp's Sales, Earnings, Costs and Acquisitions (1997-2014)

Source: Created by the authors based on Corp's public and internal documents

However, analyzing each of Corp's Business Unit (BU) separately, homogeneous behavior was not observed to demonstrate if the acquisition strategy has made any positive influence on each BU performance or not. Figure 2 demonstrates that the invested amount in acquisitions and earnings per share from 1997 to 2014 does not seem to clearly corroborate this strategy's positive influence. 


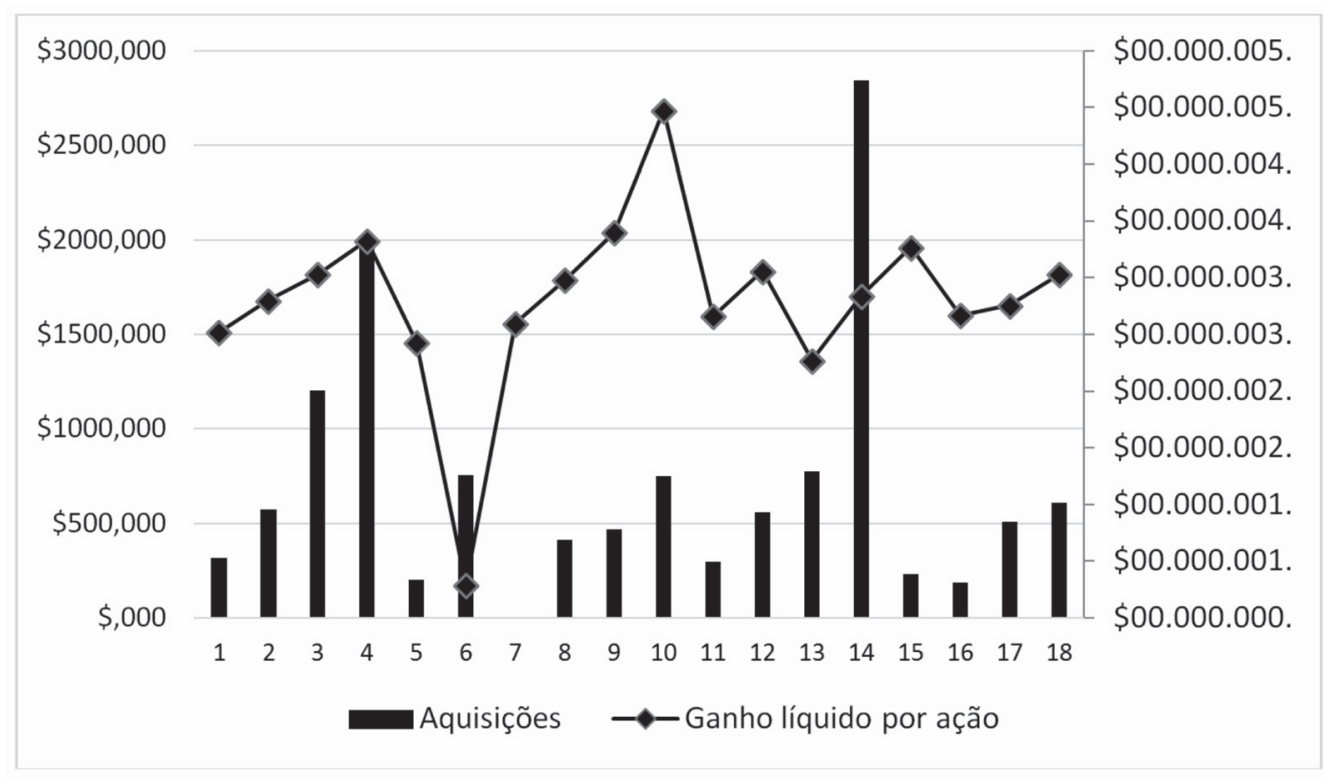

Figure 2 - Corp's Earnings per Share and Acquisitions (1997-2014)

Source: Created by the authors based on Corp's public and internal documents

By the end of the 1990s, while Corp's acquisition investments were being made, earnings per share generally obeyed a growth trend. However, amid the corporate scandals of the early 2000s, not even the higher amount dedicated to the acquisition strategy prevented the earnings per share to crumble, recovered after 2002 and maintaining an upward curve up to 2006.

From 2007 to 2009, despite the regular acquisition investments, the earning per share had oscillated and, in order to recover in 2009, amid the 2008 financial crisis impacts the company had, by 2010 , invested over US\$2.5 billion in acquisitions. Despite a raise of the earning per share, this was not proportional to the investment done, and by 2011, the earning per share dropped again. Only by 2012, it rose again, when new, but more modest investments (when compared to the 2000 and 2010 investments) were made. Due to the heterogeneous earning per share behavior, the company prefers to use another financial indicator in its annual reports to demonstrate its respect to the SHV: the distribution of dividends.

Since 2014, market analysts have been emphasizing that, in fact, the company's dividends were "the sole reason to keep" its shares. The company's largest BU was built over the past decade through acquisitions based on the assumption that its product lines demand (the supply of equipment/services to large computer server centers powering the internet) would expand. This did not happen and its sales dropped due to changes in the IT supply models. In that same year, a stressed Corp decided to sell 51\% of its BU, but the stock prices kept dropping. Leading market analysts and investors pushed the CEO/Chairman, who sold out the rest of the BU in a (desperate) attempt to be free of that BU's negative results over the whole company's results. During 2014, he kept insisting that they would not give up, but by the end of 2015, as Corp's board pressure increased, one of the latest "Wall Street trends" (Solomon, 2011) among the conglomerates trying to get rid of business lines (considering the tax-free advantages compared to an outright sale) was also undertaken by Corp - that is, the spinoff of what was left from what had been, in the past, its largest (and most powerful) BU.

The spinoff, or "the ugly stepchild of corporate strategies" (Feldman, 2015) was announced in a 
2015 conference, when Corp's CEO/Chairman, acknowledging his corporate failure, joked that he would not write that down on his tombstone. As he probably would not put the 2014 goodwill impairment of US\$ 508 million, a consequence of the overestimated 2010 acquisition made by that BU which negatively impacted company shares.

Still, the examination of the company's annual reports from 2010 to 2015 revealed, in fine print, that the released earnings per share had often included discounts related to goodwill impairment of overpaid acquisitions: US\$ 0,03 (2011), US\$ 0,72 (2012), US\$ 0,78 (2013) and US\$ 0,72 (2014). This may somehow be shaping Corp's preference to emphasize the organizational restructuring cult as the one that symbolizes its reverence to the SHV ideology, as the following case study presented.

\section{The Performative organizational restructuring act at Corp-Brazil}

Corp's Brazilian subsidiary operated, until 2014, with four of the five American BUs. By 2010, after the world financial crisis it was pressed by the American Headquarters to cut costs "in order to create shareholder value" according to all those interviewed. In order to meet this requirement, the American Headquarters proposed that the subsidiary should undertake an organizational restructuring. Although this restructuring process has not been concluded until 2013, Corp's 2010 Annual Report, already portrayed it as a successful one, emphasizing the "global restructuring program and the search for a better business mix" and presenting it as one of the reasons for the gross margin increase of that year.

\section{I The performative restructuring act} Part 1: Transforming the company's internal relationships into market relationships - The creation of Shared Services Units (SSUs)

By 2010, Corp Brazilian operations were dispersed over many sites. The company's main operation, in Sorocaba, concentrated, by
2009, nearly $25 \%$ of all Brazilian workers. The restructuring process involved centralizing all national operations in Sorocaba. This process started in 2010, when the company invited all Corp decentralized workers to move to the city. The company has also created a Voluntary Dismissal Plan for those who choose to leave the company.

A second phase of the restructuring process involved the creation of the Shared Services Units (SSUs) concept. This concept involved the centralization of five expertise fields: Human Resources, Proposals \& Quotations, Quality, Supply and Finance in Sorocaba, within a new SSU format. These expertise fields were earlier decentralized within each of the four Brazilian BUs. After the centralization, five independent units were created to sell their specific expertise to the four Business Units (BUs) in the Brazilian subsidiary, accordingly to each BU demand.

SSUs, differently from BUs, which are responsible for the production and sales of products, do not generate revenue, since they do not have external clients (only internal ones, which are BUs themselves). Therefore, all SSU costs, human resources salaries and others, have to be paid by BU revenues. Every month, SSU costs were prorated by BUs, proportionally to each service bought. BUs could, alternatively, outsource the services they needed (referring to SSU expertise) but them, paying separately the outsourced service. In sum, while BUs were profit-generating units, SSUs were made into costgenerating units, supported by BUs' revenues.

Considering the presented above, the relationship between BUs and SSUs has been mostly a conflicting one, as it involves the allocation and payment of shared (and limited) resources. Nevertheless, under specific circumstances, BUs and SSUs have engaged in a bailing out system, in which a BU can temporarily absorb another BU's costs (referring to its SSU costs), in order to deliver the Headquarters' expected numbers from each of them. Once one of the BUs risked being in the awkward position of not being bailed out 
by its counterparts, all of them informally agreed to cooperate with one another in this way, since SSU costs could heavily impact their performance. However, from 2012 on, the battles involving BUs and SSUs intensified, because, although the concept (of sharing SSU costs) has existed since 2010, it was only been fully/ physically implemented by 2012 . This means that there were cases that, even when a service was formally framed (and paid for) as a shared one, some of the activities could be still physically allocated inside one specific BU, due to, for instance, the BU's frequency of use of resources involved in the SSU field, for exemple the SSUQuality case; or as in the Human Resources case (SSU-HR), in which each of the four BUs kept their own decentralized team.
When the SSU concept was formalized (and physically centralized in Sorocaba), new managers were assigned (hired/reallocated) to systematize the earlier dispersed activities, creating conflicts and power disputes. In the case of the metrology labs, for example, following SSU-Quality centralization, the new manager created queues to schedule the BU's demands, thus upsetting powerful BU leaders that use to have previous privileges in this queue. Table 1 summarizes the payroll costs relative to the subsidiary's revenue in 2010, before restructuring, and in 2013, after it, demonstrating that the operational efficiency after SSU creation did not meet even an immediate labor cost reduction, and therefore, SHV creation requirement.

Table 1

\section{Operational efficiency of SSUs - Payroll costs/Brazilian operation revenue (2010- 2013)}

\begin{tabular}{lcc}
\hline Shared Services Units (SSUs) & $\begin{array}{c}\text { Payroll Costs/Brazilian Operation Revenue } \\
(\mathbf{2 0 1 0 )}\end{array}$ & $\begin{array}{c}\text { Payroll Costs/Brazilian Operation Revenue } \\
(\mathbf{2 0 1 3 )}\end{array}$ \\
\hline Proposals \& Quotations & 0.33 & 0.36 \\
Finance & 0.64 & 0.52 \\
Quality & 0.32 & 0.30 \\
Supply Chain & 0.38 & 0.42 \\
Human Resources & 0.28 & 0.25 \\
\hline Total & 22.48 & 22.86 \\
\hline
\end{tabular}

Source: Created by the authors based on internal documents (2015)

Each of the SSU created had its own centralization problems, conflicts and results as shown in the above table and described as follows:

- The creation of the SSU - Proposals \& Quotations involved the resistance by professionals that did not want to leave their BUs; the loss of knowledge due to professional dismissal, the new and expensive hiring; the power struggle and productivity loss, promoted a gap between the need for a multidisciplinary approach for projects elaboration and the achieved results, since, even with the creation of this SSU the process related to the proposal formulation remained unchanged;

- The creation of the SSU - Finance institutionalized the entry of accounting control discourse in the Brazilian subsidiary operation. This unit ended up being the sole one that has delivered a significant cost reduction related to the payroll costs, considering the 12 positions externalized to Costa Rica and three managers' dismissals with no replacement;

- The creation of the SSU - Quality testified the most symbolic power struggle 
among Bus and the new structure, as well as between the Brazilian operations and the American Headquarters, since the American VPs from the respective Brazilian BU pressured to (re)decentralize certain quality professionals. So new quality professional were hired to work exclusive and directly in one of the BUs, thus, becoming fixed (and duplicated) costs of this BU. Due to this, the SSU - Quality has achieved a little labor reduction cost;

- The creation of the SSU - Supply seemed to be the one in which the reengineering process had promoted the best operational results, despite with a proportional labor costs increase. The improved operational results achieved can be attributed to the absence of minimal earlier organization within this unit. In any case, inexplicably, the best operating resuls of 2013 were proclaimed in the 2010 Annual Report focusing on SSU's technical capacity. ;

- Last, but not least, the SSU - Human Resources situation, which illustrates once again the dissonance between the discourse of centralization and its symbolic result.. After the restructuring, there were created four HR units allocated to each BUs, and two of this units reported hierarchically to the head of HR allocated to the biggest BU. Some services were provided on a shared basis and others, in a dedicated manner, resulting, as an employee mentioned, in a situation where none of the tasks could be performed well, even more considering the leaves of professionals who were not replaced, resulting in a small cos reduction.

Besides theses, a rather relevant point concerning the Brazilian subsidiary symbolic organizational restructuring act refers to why the production function has remained decentralized in all four Brazilian Bus, not having been centralized in a shared services structure, despite its labor- intensive characteristics and costly activities, also considering the fact that Corp has already outsourced such activities to others Subsidiaries. The problems, however, did not stop there.

\subsection{The performative restructuring act Part 2: Conflicts, power struggles and bad results}

Although the hierarchical relationship between Brazilian BU managers and Latin America supervision has not changed due to the SSU creation, the SSUs' leadership emergence side-by-side to the BUs leadership gave the BU's leaders a perception of loss of power, since the created SSUs began to take on a more influential role (as internal service providers) than their earlier one (directly subordinate to BUs' leadership).

Before the restructuring, BUs' leaders' wishes always prevailed when conflicts related to the earlier decentralized fields (current SSUs) appeared. But, after the restructuring, every time that a conflict arose, the involved SSU leader started addressing the issue to its respective Latin American leader that began discussing it from an equivalent hierarchical position with the Brazilian BU leader, searching for a consensus, and the decision could only be reached after that. One of these conflicts has involved the Quality SSU when the largest Brazilian BU manager needed to be backed up by its respective American BU President to undo the centralization decision. In an earlier situation, this Brazilian BU manager would not even let centralization happen in the first place; or it would have the power to reverse centralization by itself, not requiring any further endorsement. That demonstrates that Brazilian BUs lost power and, according to their managers, productivity as well.

Nevertheless, we must highlight that, from the BUs managers' point-of-view, the situation could have been worse, if their four production fields (which had remained decentralized within the Brazilian BUs) had also been centralized as a shared service, which, however, did not happen, although Corp already operates in this way or 
even outsourcing production in certain Latin American countries.

Still, while managers expected to be promoted due to their workload enlargement, the Headquarters expected a sales increase and cost reduction. However, both expectations were frustrated, since managers had their responsibilities increased without any financial compensation associated to them; and the Headquarters, despite achieving a sales increase, had an associated cost increase as well. The hiring of new professionals occurred due to the work overload, instead of being planned considering the restructuring needs. Throughout 2011 and 2012, 400 people had been hired; 70\% of those have been professional addition and 30\% have been replacements generated by voluntary dismissals, dissatisfactions or unsuccessful hiring. A consequence of it was the direct costs increase related to salaries, as well as indirect costs increase related to hiring/dismissal costs and productivity losses. A manager revealed that, once the Headquarters feared the reaction of Brazilian unions, decisions related to the restructuring have been made abruptly, thus causing these problems.
Moreover, following the 2008-2009 financial crisis the Headquarters had authorized the Brazilian subsidiary to sell lower margin projects in order to win big biddings from companies as Petrobras, Braskem, Vale, etc. This decision, besides increasing the net sales, also increased the associated sales costs, heavily influenced by labor, materials and supply costs increases. Since Corp projects have longterm revenue recognition, its correspondent revenue is booked accordingly, as the project is delivered. By 2011, the intermediary deliveries, the correspondent revenue increases, and the non-auditable scenarios distorted the increase in sales costs and the subsidiary operational profit inefficiency. Moreover, as the restructuring was taking place at that period, labor reductions costs were being anxiously awaited. However, by 2013 , neither the restructuring results delivered the cost reductions, nor the lower margins projects sales delivered higher profitability and the consequences of both negative results had begun appearing by 2012 and 2013. Table 2 summarizes the Brazilian operational efficiency (2010-2013) the operational profit and the relation between the operationa profit sales (2010-2013):

Table 2

Operational efficiency in Sorocaba and operational profit over Brazilian operation sales (2010-2013)

\begin{tabular}{cccccccc}
\hline & $\begin{array}{c}\text { Total } \\
\text { Employee }\end{array}$ & Revenue (R) & $\begin{array}{c}\text { Payroll Costs } \\
(\text { PC) }\end{array}$ & $\begin{array}{c}\text { Operational Efficiency } \\
(\text { PC/R) }(\%)\end{array}$ & $\begin{array}{c}\text { Operational } \\
\text { Profit }\end{array}$ & $\begin{array}{c}\text { Operational } \\
\text { (OP) }\end{array}$ & Profit / Sales (\%) \\
\hline 2010 & 1,218 & $488,682,635$ & $109,837,883$ & 22.48 & $34,959,000$ & 7.2 \\
2011 & 1,376 & $643,093,904$ & $150,028,389$ & 23.33 & $18,475,000$ & 2.9 \\
2012 & 1,833 & $663,038,907$ & $191,831,898$ & 28.93 & $-25,225,000$ & -3.8 \\
2013 & 1,455 & $797,646,054$ & $182,333,815$ & 22.86 & $-46,610,000$ & -5.8 \\
\hline
\end{tabular}

Source: Created by the authors from internal Corp documents (2015)

According to the company CFO in Florida, both 2012 and 2013 Brazilian operational losses were enclosed by the American Headquarters, either increasing the subsidiary social capital or lending money from a profitable subsidiary operation, thus avoiding taxes and achieving foreign currency translation to the Headquarters' results. Despite all the financial engineering manoeuvers, the Headquarters exclaimed:
"What are you doing down there?! There are lots of managerial layers there. Cut them off?" Then, an even more unplanned step began, since the overloaded human resources, marketing and information technology managers had been terminated and re-hired via better remunerated outsourcing contracts. About this situation, an interviewed Corp director revealed: 
"[...] Listen, I know we did not reach the expected synergy gains...I know that, quite the opposite, we ended up spending even more. But we have to prove we can transform fixed costs into variable ones. That means we had to set the restructuring into motion anyway. From now on, we have to constantly show them that we can do it... that we are able to do what everybody else is doing, besides doing our jobs. In fact, 'doing it' became part of our job [...]" (Corp Brazilian director, 2013)

The power struggles involving the SSU' centralization, added to the empirical evidence of its negative results, contributed a great deal to a negative perception about the restructuring process among Brazilian employees. Nevertheless, from the point-of-view of SHV discourse reproduction, as the Brazilian director portrays, the restructuring process has become a "new way of life", seemingly showing that part of the subsidiary have understood the new rules of the game, internalizing the SHV ideology habitus (Bourdieu, 1989); therefore, representing a symbolic gain to the American Headquarters, and a legitimated enactment for capital market stakeholders.

Moreover, in case the 2013's restructuring imposition by the American Headquarters was not clear enough about the "new rules of the game"; the 2015's sell out of Corp's largest BU, which in Brazil, represented the shutdown of a whole unit outside Sorocaba, certainly did. This unit was the sole one, which did not move to Sorocaba, pledging by that time, the high logistics costs for the move, but perhaps, this shutdown was already in the Headquarters' horizon. Nevertheless, the unemployment threat among the subsidiary is being helpful to better commune with the Headquarters' ideology, whatever it turns out to be.

\section{The power of myth amid the Shareholder Value Management Ideology (SHV)}

The restructuring mantra has been exhaustively reproduced by large companies under
SHV ideology (Froud et al., 2006). However, according to the authors, the restructuring as well as the M\&A (and the spinoff) processes do not always accomplish what they promise, and in many cases they can prove very disappointing, especially when they promise to increase the SHV return. However, relevant market stakeholders who are part of the SHV ideology social construction, had institutionalized this discourse contributing a great deal to the restructuring myth legitimation and reproduction.

Westphal and Zajac (1998) suggested that there is vast evidence that the senior executives learned how to channel this antimanagerial impulse towards their self-enrichment through changes in their remuneration schemes. Brookman et al. (2007) also confirmed that CEOs who engaged in M\&A strategies announced layoffs, downsizings or varied restructurings had experienced increases in their remuneration in bonus formats or stock options. Dinardo et al. (1997) pointed out evidence that CEOs whose companies moved away from unions' interference also had their remuneration increased. In sum, once the executives noticed that one of the SHV ideology demands was that they should restructure their companies according to shareholders' interests, they begun implementing these cost reduction strategies which could be associated to this idea.

According to Goldstein (2012), these dynamics help us comprehend the apparently ineffective manager downsizing project. According to the author, managers announced restructuring, replaced workers with computers and ended up with redundant units due to the acquisitions. All of this in order to calm down Wall Street, while they were quietly hiring better-paid managers as they have always done (Goldstein, 2012). Some companies announced layoffs that never happened (Hallock, 2003) or happened simultaneously to new hiring (Capelli, 2000).

According to MacDuffie (1996), in 1985, the Ford Motor Co. announced a restructuring process planned to reduce $20 \%$ of manager 
positions, but, in fact, by 1989 , only $1,5 \%$ of that had been achieved. The authors' evidence show that, from early on, managers and executives in general had perceived that, to preserve themselves amidst the threat of the SHV ideology antimanagerial impulse, they would have to take on a certain dose of performativity in their discourses. According to Roe (1994), the information asymmetry experienced by investors, coupled with the political-institutional arrangements of the professional category to which managers belong, prevents the imposition of all the desires of the former are even considered by the latter.

Thus, facing the potential lack of investors' effective conditions to really manage to pressure or control companies' top management (Boyer, 2005; Lazonick, 2009; Montalban \& Sakinç, 2013) to act as they want them to act, despite what the SHV discourse preaches (Useem, 1993; Fligstein, 1990; Powell, 2001; Froud et al., 2000a); despite symbolic/performative restructurings not being sufficient to boost share values, they certainly pay an adequate reverence to those stakeholders' interests, demonstrating that their power and influence is not being ignored. Even more so considering the renewed wave of activist investors. In fact, by 2015, Corp was placed along with others industrial conglomerates in the activist investor Nelson Peltz target list (Browne, 2015).

Hirsch \& De Soucey (2006) portrayed the restructuring discourse as an important component of the American managerial ideology exported to transnational contexts, as in Corp-Brazil case. In this case, despite what the SHV discourse preaches about profit maximization being replaced by shareholder return maximization, Brazilian outcomes had not even delivered profit maximization itself (Table 2 ). Besides profitability losses, labor costs after the restructuring have been increased (Table 1), leading to discrepancies between the restructuring discourse and results announced by the company's annual reports and the reached outcomes. Nevertheless, the SSU creation had contributed a great deal to show that the "ongoing basis" restructuring (2010-2015 Corp Annual Reports) had been set in motion; as well as to, locally, catechize the subsidiary about the company's Headquarters' SHV ideology. The acquisition/spinoff announcements by Corp also, have been showing something is being done in order to meet the SHV ideology's legitimate beliefs, myths and values.

However, when comparing the space devoted to endorse both the restructuring and the acquisition/spinoff strategy myths amid Corp Annual Reports (2010-2015 Corp Annual Reports) it became clear that the first one is overemphasized by this company official literature. The restructuring strategy is the one sold as an "ongoing basis", despite the fact that it neither has a formal structure which supports itself (such as the acquisition/spinoff strategy has), nor is it the beneficiary of higher investments (such as the acquisition/spinoff strategy is, as company annual reports data revealed how much has been directed to each strategy since 1997). Despite of it, all Corp's stories that involve overcoming setbacks address the restructuring of operations strategy as the one, which had reversed bad numbers (20102015 Corp Annual Reports). Still, considering Corp Annual Reports' storytelling, it is worth perceiving that the acquisition/spinoff strategies employment, despite, being opposite strategies, can be used to meet the same argument: to create shareholder value. Using the same logic to employ both strategies, it starts making sense that, in 2010, the company acquired another company in order to create shareholder value - but, by 2016, the company sold the very same company to create shareholder value.

Considering, now, the restructuring of operations strategy undertook in the Brazilian subsidiary, as the battles around how much each BU had to, monthly (and proportionally) pay to each shared service used (related to the Proposals \& Quotations, Quality, Finance, Human Relationship and Supply Management) it provoked not just an unproductive environment, as an hostile and an anti-economic one; leading 
one BU to duplicate the service already provided by an inside shared service unit (SSU - Quality). Nevertheless, despite these huge fights situation, there were times when quite the opposite situation was verified, that is, the bailing-out system among BUs and SSUs, however, without the company benefiting from it. That is, even though the shared services concept has been thought to make BU physical results more productive (to which they have hardly contributed) and the financial ones, more transparent (to which they clearly did not contribute) they kept (along with the BUs) redistributing their costs, bailing-out the BUs, when necessary, in order to deliver the expected numbers. So, despite the SHV discourse of transforming the company internal relationships into market relationships, (disclosing each individual BU results, stimulating the competition among them, and enabling their results to be independently measured, compared and employed towards investment or disinvestment decisions); this bailing-out arrangement has neither reflected reality, nor stimulated competition among them, on the contrary, having stimulated cooperation (in the bad sense from the point of view of SHV) between them.

As USC leadership emerged side by side with established UN leaders, other conflicts over power disputes have emerged together with a perception of a symbolic organizational upsizing situation instead of the downsizing one sought, and as a result even the direct labor costs were not achieved, with some of the dismissed managers rehired with higher wages. These facts raised many questions inside the subsidiary and more hostility among the organizational units, employees, managers and directors. A rather relevant point concerning Corp-Brazil's symbolic restructuring act refers to why the production field had not been centralized in a shared service structure in spite of its labor-intensive and costly activity characteristics, and despite the fact that Corp was already production outsourced in other American Latin subsidiaries.

As Froud et al. (2006) "any consideration of restructuring takes us further into the issues around saying and doing and the multiple discrepancies around both" (Froud et al., 2006, p.109). The discrepancies between the discourse (of creating SHV through this organizational restructuring) and the reached outcomes (of increased labor costs) revealed by the SSU creation (intended to transform company relationships into market ones) were only perceived by some of this process survivors. They had neither been perceived by those enjoying the successive 59 years of increasing dividends; nor by influential capital market stakeholders, whom the performative restructuring act had been played to. To them, the company annual reports portrayed the restructuring as a well-succeeded process, which, by the way had not caused any awkward goodwill impairment which could diminish the share value gains, thus, partially explaining the company's preference to overstate this strategy in its annual reports as the belief that most symbolize its reverence towards the SHV ideology.

\section{Final considerations}

The paper sought to introduce an alternative and interesting conceptual connection among the speeches directed to the American Management throughout the decades of 1950, 1970 and 1990; the Theory of the Agency and the social construction of the organizational field of management ideology focused on the valuation of the shareholder; SHV, which could somehow push forward organizational studies. In this sense, the contributions of this paper may be threefold. The management ideology, as presented here, goes beyond the traditionally used agency theoretic formulations of the SHV and employs the bourdieusian notion of fields to better explain SHV ideology's legitimized beliefs. It also, integrates the 1970s' management discourse reorientation and the construction of the SHV organizational field with the emergence of the phenomenon called the Celebrity CEO. At last but not least, another contribution of it lies within the imbrication of theories and empirical findings deduced from its detailed (and longstanding) case, studied from 2010 and 2015. 
Further studies related to this theme could consider analyzing other Corp subsidiaries' restructuring processes, viewing to compare them with the one undertaken in Brazil; or explore and compare Corp competitors' strategies under the SHV ideology pressure. Moreover a third suggestion would be trying to overcome a somehow limitation found by this research, that is, seeking to understand, how, each isolated subsidiary results affects the company's general results in terms of creating or destructing shareholder value. Although the reached restructuring outcomes neither reducing subsidiaries' costs nor improving their profitability - enable us to state that they did not create shareholder value, it would be interesting to understand, quantitatively, how (and if) they destroyed shareholder value.

The objective of this paper was to explore a restructuring process, here portrayed as a legitimate belief/myth derived from Shareholder Value organizational field construction, undertaken in a Brazilian subsidiary of a century-old American public corporation. According to this company's statements/discourse (repeatedly reproduced by its interviewed CFO/directors/managers and by public official documents), the company shares this belief, among others values, myths and rituals, that is, its habitus, legitimated as share value creators by the SHV ideology.

According to Froud et al. (2006) institutional investors' pressure had led managers to proclaim the restructuring myth, in all its forms, as a recurrent way to show that their discourses were being enacted, but, as time went by, making the speech correspond to the action had proven a tough task, leading the authors to wonder:

"If restructuring can be the site of some major discrepancies between saying and doing because the ex-ante objective may be increasing the returns for shareholders but the ex-post outcome for capital is often disappointing, despite labor cost reduction strategies, why does management insist on restructuring?"(Froud et al., 2006, p. 109).
This illustrates the state of affairs at Corp, although in this case, not even the straightforward labor cost reductions have been reached. The authors' answers to the above questioning match a Corp director's speech: "companies insist on doing that, because it shows that something is being done." Still, according to the authors, it makes companies under the capital market pressure buy time, as the serial restructurings make it difficult to evaluate and/or compare companies that frequently keep changing their formats (Froud et al., 2006).

In addition, as another Brazilian director mentioned, they were following the continuously restructuring fad, as "we have to show that we are capable of doing what everyone is doing." Considering the obsessive nature of this mimetic isomorphism (DiMaggio \& Powell, 1983), this organizational homogenization process has been driving organizations' moves, seemingly without making them more efficient (Sacomano Neto et al., 2013). Indeed, for large companies under the SHV ideology (and the financialization and capital market pressures) some of the changes undertaken are less oriented by technical efficiency demands, and more by the legitimacy demand of being perceived as value creators, thus impelling the mythic restructurings. Paraphrasing Dobbin and Jung (2010), when market makers stakeholders believe that companies under recurrent restructurings (or that appoint Celebrities CEOs, or that invest in M\&A, etc.) are more value creators, than...they are. Also, according to Bourdieu (1989) the discourses' content, and more specifically, the symbolic power that their words exert, lie in the legitimacy that listeners confer to those who pronounces them.

The studied case have shown that the analyzed company reproduces the legitimated beliefs under the SHV ideology, through both its formal and informal discourses, as also through their enactments, thus symbolizing its reverence towards that ideology. The Brazilian restructuring process meant both; to reproduce the belief of transforming the companies' internal relationships into market ones, as also; the belief 
of the restructuring process be one capable of creating shareholder value. However, so far, three years after the end of the Brazilian restructuring process, it has neither proven capable of effectively transforming its internal relationships into market ones, as the development of the bailing out system among SSUs has; nor was it sufficient to boost the company's share values (as neither straightforward cost reduction nor profit increases were reached). Nevertheless, the company annual reports' narrative about its ongoing restructuring strategies' virtues of creating shareholder value has been reinforced by the Brazilian (performative) restructuring process, especially considering that:

- The 2010 Corp annual reports, already portrayed the Brazilian restructuring results (only reached in 2013) as successful ones;

- The sole piece of disaggregated public information concerning Corp's geographical results provided by its annual reports informs that the sales' evolution per World Area (country grouping defined by the company) is growing (as also are the Brazilian's sales costs);

- These results had neither be perceived by Corp shareholders, nor by influential American capital market stakeholders;

- These results did not imply I any embarrassments goodwill impairments, as some acquisition moves may cause;

- The subsidiary's catechization on behalf of the SHV ideology. Despite the fact that this may represent an important symbolic gain, this is not the result that the company report refers to;

- This issue also involves symbolic aspects related to the organizational management field, in this sense, not only quantitative results may be considered; and

- The effective control of any company top management by the investors may be questionable (Boyer, 2005; Lazonick e O’Sullivan, 2000; Montalban e Sakinç,
2011). Still, even though, highly symbolic, these actions play an important role related to those stakeholders' interests, proving that their relevancy is not being ignored.

As Geertz (1973), quoting Weber, stated, "man is an animal suspended in the webs of significance that he himself has spun" (Geertz, 1973, p. 15). So, he keeps inventing terms, attributing meanings to them and, then, employing them in order to structure his reality (Berger \& Luckman, $1966)$ as if it was not a product of a previous action of he himself. The social construction of the SHV Ideology field is an emblematic case, in which stakeholders kept building their impressions about the (perceived) environment and then responding accordingly to the market makers stakeholders expectations (of ongoing restructurings) as they were forced to it, when, in fact, it was each ones activism within this field construction, that forged such a condition, through which they expected to benefit themselves somehow. By this way, managers enact their symbolic/performative acts, as they perceive them, structuring their reality as recipients of millionaire bonuses. In others words, markets are socially constructed in order to adapt themselves to the most influent stakeholders' interests engaged in this construction, or still, the social arrangements construct the markets and not the contrary (Fligstein, 1990).

This can be perceived in the social construction of the Management organizational field, from the late 1970s, marked by the reorganization of its discourse due to the Shareholder value management ideology, boosted by the influential institutional investors interests, which began occupying a highly privileged position within the SHV organizational field due to its less pulverized condition after the 1980s financial deregulation. The institutionalization of this ideology installed a management model based to the shareholder value creation, and thus, highly susceptible to the scrutiny of the other influential capital market stakeholders.

Despite this scrutiny, the fiasco of SSU establishment - which elevated dissonance between 
discourse and results to previously unthought-of heights -, the symbolic restructuring of Corp has proven to be sufficiently convincing, so far, to avoid the centralization (or outsourcing) of its production operations, while in other places Corp already outsources them. The maintenance of an intensive productive operations at Corp-Brazil, in a decentralized way (that is, involving process duplicity) in each of the four Bus, while facing the restructuring process taking place, is a strong evidence that restructuring had a rather symbolic trend, since those operations should be the first to be included within the restructuring process, if this process was, really determined to cut costs, despite the fact that the discourse intended to create value to the company. Despite the fact of these (non-financial) productive operations be measured and controlled through financial metrics, the fact of Corp had kept its decentralized structure might be a signal that the financial logic has not (yet and entirely) replaced the productive one, opposing another belief under the SHV ideology (Grün, 1999). This is also clear when analyzing the company's Annual Reports, which overly value the organizational restructuring strategy (based on production logic) instead of the strategy based on acquisition/divestment (based on financial logic) to symbolize the company's belief in SHV ideology.

This is not to say that the inorganic growth through the acquisition strategy is not a highly representative of the company's SHV ideology creed, since, everywhere, in the same annual reports (and the interviews and company actions in this direction) reveal how heavily the company invests in this strategy, both through financial investments as well as through a formal structure established to serve it in the quest for potential targets. According to the interviewed $\mathrm{CFO}$, one cannot compare productivity gains that result from a new layout design (and their reflections on financial gains) with gains resulting from the acquisition of another company (and its reflections, including the incorporation of EBITDA, of sales revenue, cash flow, new product lines etc. from the acquired company).

Nevertheless, the performative restructuring strategy is still at the forefront, emblematically symbolizing company adherence to SHV ideology. Maybe this is due to the constraints caused by acknowledging faulty acquisitions or the adoption of the "ugly stepchild of corporate strategies", (Feldman, 2015) creating bizarre situations in which, paradoxically, both acquisition and spinoff decisions are based on the same arguments: the creation of results for shareholders. These results, however, are not coming. For neither the billions of dollars invested in acquisitions in 2010; nor 2014's disappointing results from the 2013 Brazilian restructuring; nor the selling of $51 \%$ of its largest BU to a Private Equity Fund in 2014; nor 2015's spinoff announcement of the remaining $49 \%$ of that $\mathrm{BU}$ have managed to stop Corp's falling stock prices over the last two years.

Paradoxically, however, operating under the cold logic of finance and pressured by the (quantitative) imperative of value creation, the analyzed company has revealed itself subject to organizational dynamics in which the quest for symbolic legitimacy plays a decisive role in preserving its position within the hierarchy of the socially constructed SHV field, thus reinvigorating Field Theory (Bourdieu, 1989) and the Neo-Institutional Theory (DiMaggio \& Powell, 1983) concepts, and Agency Theory formulations (Jensen \& Meckling, 1976).

According to Boden (1994), the fundamental structuring process of organizations is speech. Jönsson (1988), on the other hand, argues that "managers work with words" (Jönsson, 1988, p.411). Well, the words with which managers "work" depend on whom they are speaking to. The SHV audience proved to be demanding, pressuring managers not just to speak, but also to act according to what it wanted to see, hear and read. Accordingly, the company's annual reports proudly promise: "At Corp, we do what we say we are doing", so any gap between discourse and outcome can be presented as an opportunity 
to do more (as well as to speak more), since the same report also announces: "there is much more to come", (or "to go", maybe through another spinoff...).

\section{References}

Benatti, G. (2016). O Ato Performático da Reestruturação: Dissonâncias entre o Discurso e os Resultados em um Estudo de Caso Brasileiro sobre Financeirização. Dissertação de mestrado, Universidade Federal de São Carlos, Sorocaba, São Paulo, Brasil.

Berger, P.L., \& Luckman, T. (1966). The Social Construction of Reality: A Treatise in the Sociology of Knowledge. Garden City, NY: Anchor Books.

Bloomberg (1995). Accessed at: http://www. bloomberg.com on January, 17, 2015.

Boden, D. (1994). The Business of Talk. Organizations in Action. Cambridge, England: Polity Press.

Boje, D.M., Oswick, C., \& Ford, J.D. (2004). Language and Organization: The Doing of Discourse, Academy Management Review, October, 29 (4), 571-577.

Bourdieu, P. (1989). O Poder Simbólico. Rio de Janeiro, Brazil: Bertrand Brasil.

Boyer, R. (2005). From Shareholder Power to CEO Power. The paradox of 90s. Working Paper 2005 - 10. Paris-Jourdan Sciences Economiques. Accessed at: http://hal. archives-ouvertes.fr/docs/00/59/08/48/ PDF/wp200510.pdf on October 8, 2010.

Brookman, J., Chang, S., \& Rennie, C. (2007). CEO Cash and Stock-Based Compensation Changes, Layoff Decisions and SHV, Financial Review, 42, 99-119.

Browne, C. (2015). RBC: Nelson Peltz May Target One Of These Industrial Companies Accessed at: http://www.valuewalk.com/2015/05/ nelson-peltz-activist-targets/ on November $18,2015$.

Capelli, P. (2000). Examining the Incidence of Downsizing and its Effect on Organizational Performance. In Neumark (Ed) On the Job: Is Long-Term Employment a Thing of the Past? New York: Russell Sage Foundation, 463-516.

Cartwright, S., \& Schoenberger, R. (2006). Thirty Years of M\&A Research: Recent Advances and Future Opportunities, British Journal of Management, 17 (S1), S1-S5.

Deloitte (2012) How Companies Can Improve Value Through M\&A - Beating the Odds. Accessed at: http://www2.deloitte.com/us/ en/pages/mergers-and-acquisitions/articles/ how-companies-can-improve-value-throughmergers-and-acquisitions.html on July 15, 2013.

DiMaggio, P.J., \& Powell, W.W. (1983). The Iron Cage Revisited: Institutional Isomorphism and Collective Rationality in Organizational Fields. American Sociological Review 48, 147-160.

Dinardo, J., Hallock, K., \& Pischke, J.S. (1997). Unions and Managerial Pay'. NBER Working Paper Series, Vol.w6318. Accessed at: http://www.nber.org/papers/w6318 on January 06, 2014.

Dobbin, F., \& Jung, J. (2010). The Misapplication of the Mr. Michael Jensen: How Agency Theory Brought Down the Economy and Why It Might Again. Markets on Trial: The Economic Sociology of the US Financial Crisis: Part B. Research in the Sociology of Organizations 30B: 29-64. Accessed at: http://scholar.harvard.edu/dobbin/ publications/misapplication-mr-michaeljensen-how-agency-theory-brought-downeconomy-and-why- on March 18, 2014. 
Eccles, R.G., Lanes, K.L., \& Wilson, T.C. (1999). Are you paying too much for that acquisition? Harvard Business Review 77 (4): 136-146. Accessed at: http://hbr.org/1999/07/areyou-paying-too-much-for-that-acquisition/ sb1 on December 14, 2010.

Feldman, E.R. (2015). Managerial compensation and corporate spinoffs. Strategic Management Journal. doi: 10.1002/smj.2434.

Fleming, P., \& Spicer, A. (2014). Power in Management and Organization Science. The Academy of Management Annals, 8 (1), 237-298.

Fligstein, N. (1990). The Transformation of Corporate Control. Cambridge, M.A: Harvard University Press.

Fridolfsson, S.O., \& Stennek, J. (2005). Why Mergers Reduce Profits and Raise Share Prices-A Theory of Preemptive Mergers. Journal of the European Economic Association 3 (5), 1083-1104.

Froud, J., Johal, S., Leaver, A., \& Williams, K. (2000). Restructuring for SHV and its implications for labour. Cambridge Journal of Economics 24, 771-797. doi: 10.1093/ cje/24.6.771.

Froud, J., Johal, S., Leaver, A., \& Williams, K. (2006). Financialization and Strategy. 1 st ed. Oxion: Routledge.

Geertz, C. (1973). A interpretação das Culturas. Rio de Janeiro, Brazil: Zahar.

Goldstein, A. (2012). Revenge of the Managers: Labor Cost-Cutting and the Paradoxical Resurgence of Managerialism in the SHV Era, 1984 to 2001. American Sociological Review 77 (2), 268-294. doi:10.1177/0003122412440093.

Grün, R. (1999). Modelos de Mundo, Modelos de Empresa: Sobre Algumas Características
Culturais da Nova Ordem Econômica e da Resistência a Ela. Revista Brasileira de Ciências Sociais, 14 (41), 121-140.

Hallock , K. (2003). A Descriptive Analysis of Layoffs in Large U.S. Firms Using Archival and Interview Data: 1970-2002. Unpublished paper, Department of Economics, University of Illinois. Accessed at: http://digitalcommons.ilr.cornell.edu/ articles/236/ on February 23, 2015.

Hayward, M. L. A., Rindova, V., \& Pollock, T. (2004). Believing one's own press: The causes and consequences of CEO celebrity. Strategic Management Journal, 25 (7), 637-653. doi:10.1177/0003122412440093.

Herd, T. J., \& McManus, R. (2012). Who Says M\&A Does Not Create Value? Accenture. com/Outlook 1: 1-13. Accessed at: http:// www.accentureconsulting.no/Microsites/ asia-go-global/Documents/pdfs/page-4/ Accenture-who-says-ma-doesnt-create-value. pdf on July 15, 2013.

Hirsch, P. M., \& De Soucey, M. (2006). Organizational Restructuring and its Consequences: Rhetorical and Structural. Annual Review of Sociology, 32, 171-189. doi:10.1146/annurev. soc.32.061604.123146.

Henry, O. (1992). Entre savoir et povoir. Actes de la Recherche en Sciences Sociales, 95, 37-54.

Jensen, M.C., \& Meckling, W.H. (1976). Theory of the Firm: Managerial Behavior, Agency Costs and Ownership Structure. Journal of Financial Economics, 3, 305-360.

Jespersen, F. F. (2002). Why Most Big Deal Do Not Pay Off? Bloomberg. Accessed at: http://www. bloomberg.com/bw/stories/2002-10-13/ mergers-why-most-big-deals-dont-pay-off on June 10, 2014. 
Jönsson, S. (1998). Relate Management Accounting Research To Managerial Work! Accounting, Organizations and Society, 23 (4), 411-434. doi:10.1016/S03613682(97)00018-4.

Lazonick, W. (2009). Sustainable Prosperity in the New Economy? Business Organization and High-Tech Employment in the United States. Kalamazoo, EUA: Upjohn Institute for Employment Research.

Leão, A.L.M.S.; Gaiāo, B.F.S.; Souza, I.L.; Mello, S.C.B. (2013) O Habitus de uma Rede em Expansão: As Disposições do Arranjo Vinícula do Vale do São Francisco. Revista Brasileira de Gestão de Negócios, 15(46), 3955. doi: 10.7819/rbgn.v15i46.960.

Macduffie, J.P. (1996). Automotive White-Collar' in Broken Ladders: Managerial Careers. In: P.Osterman (Ed.) The New Economy. New York: Oxford University Press, p.81-125.

Marshall, J. (2001). Are Mergers Paying Off? Financial Executive, 17 (2): 26p. Accessed at: http://www. thefreelibrary.com/ARE+MERGERS + PAYING+OFF.-a072120156 on March 14, 2014.

Meyer, J.W., \& Rowan, B. (1977). Institutionalized Organizations: Formal Structure as Myth and Ceremony. American Journal of Sociology, 83(2), 340-363..

Montalban, M., \& Sakinç, M. E. (2011). How financialization shapes productive models in pharmaceutical industry: the domination and contradictions of the blockbuster productive model. Université de Bordeaux GREThA UMR CNRS 5113: 35p. Accessed at: http:// www.theairnet.org/files/research/Sakinc/ Matthieu\&Erdem_23022011.pdf on July 19, 2013.

Nasdaq. Accessed at: http://www.nasdaq.com on September, 2015.
Powell, W.W. (2001). The Capitalist Firm in the Twenty-First Century: Emerging Patterns in Western Enterprise. In The TwentyFirst Century Firm - Changing Economic Organization in International Perspective, P. J. DiMaggio (Ed.) New Jersey, EUA: Princeton University Press.

PWC (2013). Inorganic Opportunities to Drive Growth and Increase SHV Fueled US Oil\&Gas M\&A Activity in 2013. Accessed at: http://www.pwc.com/us/en/ press-releases/2014/q4-energy-ma-pressrelease.jhtml on July 15, 2013.

Roe, M. (1994). Strong Managers, Weak Owners: The Political Roots of American Corporate Finance. Princeton, NJ: Princeton University Press.

Sacomano Neto, M.; Truzzi, O.M.S.; Kirshbaum, C. (2013). Isomorfismo e Controle Institucional em uma Planta Modular da Indústria Automobilística. Revista Brasileira de Gestão de Negócios, 15 (49), 524-544. doi:10.7819/rbgn.v15i49.1585.

Sinha, P. N., Inkson, K., \& Barker, J. R. (2012). Committed to a Failing Strategy: Celebrity CEO, Intermediaries, Media and Stakeholders in a Co-created Drama. Organization Studies 33 (2), 223-245. doi:10.1177/0170840611430591.

Solomon, S.D. (2011). A Test to See if the Parts Are Worth More Than the Whole. Accessed at: http://dealbook.nytimes.com/2011/01/18/atest-to-see-if-the-parts-are-worth-more-thanthe-whole/?_r=0 on November 18, 2015.

Useem, M. (1993). Executive Defense: Shareholder Power and Corporate Reorganization. Cambridge, EUA: Harvard University Press.

Wade, J.B., Porac, J. F., Pollock, T. G., \& Graffin, S. D. (2006). The burden of celebrity: The impact of CEO certification contests on 
CEO pay and performance. Academy of Management Journal, 49, 643-660.

Westphal, J., \& Zajac, E. (1988). The Symbolic Management of Stockholders: Corporate Governance Reforms and Shareholders Reactions. Administrative Science Quarterly, 43, 127-153.

Westphal, J., \& Zajac, E. (2001). Decoupling Policy from Practice: The Case of Stock
Repurchase Programs. Administrative Science Quarterly, 46, 202-228.

Zajac, E., \& Westphal, J. (2004). The Social Construction of Market Value: Institutionalization and Learning Perspectives on Stock Market Reactions. American Sociological Review, 69, 433-457.

\section{Supporting agencies:}

Capes e CNPq

\section{About the authors:}

1. Patrícia Saltorato, PhD in Production Engineering, Federal University of São Carlos (UFSCar Sorocaba), Brazil. E-mail: patriciasaltorato@gmail.com.

2. Glauco Benatti, MS in Production Engineering, Federal University of São Carlos (UFSCar Sorocaba), Brazil. E-mail: gbhizido@yahoo.com.br.

\section{Note:}

A preliminary version of this article was presented on Fifth Global Entrepreneurship Monitor Research Conference (Cartagena de Indias - Colombia), held on october 6 and 8, 2011; RENT XXVI - Research in Entrepreneurship and Small Business (Lyon - France), held on november 21 and 23, 2012, authors autores Eduardo Gómez Araujo, Esteban Lafuente e Yancy Vaillant. For this version, the article had update parts.

\section{Contribution of each author:}

\begin{tabular}{lcc}
\hline Contribution & Patrícia Saltorato & Glauco Benatti \\
\hline 1. Definition of research problem & $\sqrt{ }$ & $\sqrt{ }$ \\
2. Development of hypotheses or research questions (empirical studies) & $\sqrt{ }$ \\
3. Development of theoretical propositions (theoretical Work) & $\sqrt{ }$ & $\sqrt{ }$ \\
4. Theoretical foundation/ Literature review & $\sqrt{ }$ \\
5. Definition of methodological procedures & $\sqrt{ }$ & $\sqrt{ }$ \\
6. Data collection & & $\sqrt{ }$ \\
7. Statistical analysis & & $\sqrt{ }$ \\
8. Analysis and interpretation of data & $\sqrt{ }$ \\
9. Critical revision of the manuscript & $\sqrt{ }$ \\
10. Manuscript Writing & $\sqrt{ }$ & $\sqrt{ }$ \\
\end{tabular}

